\title{
Diversion in the Settlement of Child Cases to Realize Restorative Justice in Richard A Posner's Theory View
}

\author{
Subekti ${ }^{1}$, Hartiwiningsih ${ }^{2}$, I Gusti Ayu Ketut Rachmi Handayani ${ }^{3}$ \\ ${ }^{1,2,3}$ Universitas Sebelas Maret \\ Surakarta, Indonesia \\ subekti@staff.uns.ac.id
}

\begin{abstract}
This study aims to analyze the principles of diversion in view of Richard A Posner's theory of legal efficiency. The economic analysis of law approach is used to analyze diversion arrangements in Law Number 11 of 2012 concerning the Juvenile Criminal Justice System in order to realize restorative justice. The research method used is normative legal research, using primary legal materials and secondary legal materials. The results show that the diversion regulation in the SPPA Law according to the study of efficiency theory from Richard A Posner can achieve restorative justice and reduce the costs needed in the juvenile criminal justice process and reduce the overpopulation of correctional institutions. Settlement of child cases out of court (diversion) as regulated in Law Number 11 of 2012 concerning the Juvenile Criminal Justice System (SPPA) as a spirit in the protection of children in conflict with the law has not had a positive impact. The rate of detention of children is still quite high. Data from the Directorate General of Corrections (Ditjenpas) shows that the number of juvenile detainees is still quite high since the enactment of the SPPA Law. The concept of diversion is intended to avoid stigmatization of children in conflict with the law and to provide protection for victims. It is time for a retributive approach to resolving children's cases to be replaced with a restorative approach, so that it is not a punishment/retaliation, but a restoration back to its original state through the provision of restitution (reparations) to the victim as a result of the agreement between the perpetrator and the victim.
\end{abstract}

Keywords- Children, Diversion, Economic Analysis of Law, Restorative Justice.

\section{INTRODUCTION}

The resolution of children's problems in conflict with the law is an interesting problem to study, because children have rights that are specifically different from adults. Children are the mandate of God Almighty, in which the dignity and worth as a whole human being is attached. As an individual, every child, both born and still in the womb, must get their rights without the child asking. The protection and fulfillment of children's rights as part of Human Rights is guaranteed in Article 28B Paragraph (2) of the 1945 Constitution of the Republic of Indonesia, which states that; "Every child has the right to survive, grow and develop and has the right to protection from violence and discrimination." changes twice through Law Number 35 of 2014 and Law Number 17 of 2016 and Law Number 11 of 2012 concerning the Juvenile Criminal Justice System.[1]
The reason for the change of Law Number 3 of 1997 concerning Juvenile Court to Law Number 11 of 2012 concerning the Juvenile Criminal Justice System, according to Doiani Sadiawati, Director of Legislative Analysis at National Development Planning Agency, was due to several factors, including: first, the juvenile justice system's failure to produce justice; second, criminal acts and child recidivism have not decreased; third, the judicial process failed to treat children; and fourth, the court system failed to treat children. fifth, a too legalistic perspective.[2]

Children must be shielded against the harmful effects of globalization and the advancement of technology and knowledge, as well as changes in lifestyle and parental attitudes, as well as social developments that influence children's values and behavior. Children in dispute with the law (children accused of performing criminal activities) should not only be judged on the basis of their deviant behavior, but also on the basis of their long-term interests. The "Convention on the Rights of the Child," which was ratified by Presidential Decree No. 36 of 1990, must be referred to when discussing legal protection for children. The passing of Law Number 11 of 2012 governing the Juvenile Criminal Justice System confirms Indonesia's commitment to child safety. This law introduces the concept of diversion, which aims to provide protection for children in conflict with the law, children who are victims of criminal acts, and society in general by transferring the resolution of children's cases from the criminal justice system to non-criminal processes in order to achieve restorative justice.[3]

In many ways, the juvenile justice system differs from the adult criminal justice system. All activities involving the examination and decision of cases involving the interests of minors are included in juvenile criminal justice. There are multiple interconnected parts in the Juvenile Criminal Court, including Child Investigators, Child Public Prosecutors, Child Judges, and Child Correctional Officers. The rights of children are the foundation for the creation of laws and regulations controlling the Criminal Justice of Children. Because the preservation of children's rights is a major milestone in juvenile criminal justice, a fair juvenile criminal justice system ensures that children's rights are protected as suspects, defendants, and convicts/convicts.[4]

In the criminal justice system with a retributive approach, it is usually followed by means of coercion, for example; arrest and detention of someone suspected of committing a crime, as well as in the case of minors. Provisions for detention of children are possible if the child is 14 years old and the crime committed is 
punishable by imprisonment of 7 (seven) years or more. The maximum period of detention for children is 110 days (from the level of investigation to the legal process of cassation) and the placement of juvenile detainees is in the Temporary Child Placement Institution (LPAS). Data from Directorate General of Corrections states that; the number of juvenile detainees is still quite high since the enactment of Law Number 11 of 2012 concerning SPPA (July 30, 2014).[5]

Table 1. The number of child prisoners for the period 2015 to 2019

\begin{tabular}{ccccc}
\hline No. & Year & Prisoner & Prisoners & Amount \\
\hline 1 & 2015 & 663 & 2.271 & 2,934 \\
\hline 2 & 2016 & 905 & 2,319 & 3.224 \\
\hline 3 & 2017 & 1.010 & 2.469 & 3,479 \\
\hline 4 & 2018 & 894 & 2,154 & 3.048 \\
\hline 5 & 2019 & 563 & 2,026 & 2,589
\end{tabular}

Source: Data from Ditjenpas, Ministry of Law and Human Rights

From this data, it can be calculated that the cost of food for prisoners is an average of 600 children per year with a detention period from the investigator level to the judge's decision at the district court level for 50 days (the maximum detention period at the investigator level is 15 days, 10 days at the district court level). prosecution and 25 days for the examination process at the District Court), then the cost required to eat prisoners annually is $600 \times 50$ x Rp. $20,000.00=$ Rp. 600,000,000.00 (six hundred million rupiah)/convict. Meanwhile, the average number of child prisoners every year is 2,240 children. Data for the length of imprisonment imposed by the court is not yet available. Assuming that each child is sentenced to prison for one year, the cost of food that must be provided is $2,240 \times 360$ (days) $\times$ Rp. $20,000.00=\mathrm{Rp} .1,612,800$. 000 (one billion six hundred twelve million eight hundred thousand rupiah). So the total cost of eating for one year for the process of law enforcement in child cases requires a budget of 2.2 billion a year. Meanwhile, with the condition of the overpopulation of community institutions, maximum guidance cannot be carried out.so that no benefit can be obtained from a child who commits a crime and is resolved through criminal justice. In addition to the absence of benefits, children will also receive a negative stigma and this will have a wider negative impact, both psychologically and socially.[6]

The restorative justice paradigm is a breakthrough that is developing in the world to overcome the weaknesses of the criminal justice system that does not bring benefits to children as perpetrators of crimes and the absence of protection for victims. Through diversion in the form of deliberation to achieve restorative justice, at least efforts are made to establish relations between the parties concerned, the community and the state to resolve conflicts resulting from criminal acts. The results of the diversion agreement in the paradigm of restorative justice emphasize collective resolution for the good/future of the perpetrator (children) and the protection of victims and the achievement of balance and order in society. [7]

The author also argues that when a child who commits a crimelabeling himself as a "victim" of the criminal law system, then any effort in it gets a big rejection which in the end the goal of convicting children in conflict with the law will certainly not be achieved. Conditions like this of course raise a lawsuit about justice and the deterrent power of the sentence imposed.[8]

Empirically based on experience following the criminal justice process in Indonesia, it turns out that there are many non-legal factors which according to theory should not exist but in the field become a real part of the Indonesian criminal law system. The involvement of the above conditions has caused various distortions in law enforcement. Almost all stages and phases in the legal process, are perceived as a dark passage that is tense and full of puzzles, so that justice seekers are always haunted by anxiety, fear, and uncertainty [5]. So, it is not surprising that the legal process is often passed by trial and error, speculation, gambling, and chance. The atmosphere of the legal process like this has been proven to open up a bargaining place, so it is not surprising that the law enforcement space is easy for case brokers to enter. So as Sigit Pamungkas said, "law enforcement has been manipulated in such a way that justice has almost been killed in the name of law enforcement".[5]

This critical assessment is needed to know that the guarantee of protecting the best interests of children through the diversion process (in the SPPA Law) can be achieved on the basis of maximizing efficiency.legal protection for children both as perpetrators of criminal acts as well as victims and the community. It is at this point that Richard A Posner's thesis on economic analysis of law can be used as a method of approach whereEconomic analysis of law usually emphasizes the effectiveness of the law on behavior, but not victim compensation.[9]

\section{RESEARCH METHOD}

This study uses a normative juridical approach, namely by analyzing secondary data in the form of legal materials, especially primary legal materials and secondary legal materials, and supported by a statutory approach and a comparative approach.[10]

Normative legal research is research conducted by examining library materials. According to Soerjono Soekanto and Sri Mamuji, normative legal research includes: (1) research on legal principles; (2) research on legal systems; (3) research on the level of vertical and horizontal synchronization; (4) legal comparisons; and (5) legal history.[11] 


\section{FINDINGS AND DISCUSSION \\ 1. Diversion Arrangements for Child Case Settlement}

Law Number 11 of 2012 concerning the Juvenile Criminal Justice System which replaced Law Number 3 of 1997 concerning Juvenile Court which was carried out with the aim of realizing a court that truly guarantees the protection of the best interests of children who are in conflict with the law as the nation's successor. The basic substance of the juvenile criminal justice system law is diversion which has the main principle, namely as a persuasive action or approach and providing opportunities for perpetrators to change and invite perpetrators to be responsible for their actions. The restorative justice approach places perpetrators, victims, families, communities and related parties to resolve conflicts due to criminal acts fairly by emphasizing restoration to its original state without retaliation. Children in conflict with the law are children who are 12 years old and not yet 18 years old who are suspected of committing a crime.[12]

Restorative justice is an approach to justice based on the philosophy and values of responsibility, openness, trust, hope, healing and "inclusiveness" that focuses on reparation for losses due to criminal acts, in addition to trying to encourage perpetrators to be responsible for their actions, through giving opportunities for parties directly affected by criminal acts, namely victims, perpetrators and the community by identifying and paying attention to their needs after the occurrence of a crime, and seeking a solution to the problem in the form of healing, reparation, and reintegration as well as preventing further losses.[13]

The crime committed must be a criminal act punishable by imprisonment for less than seven (seven) years, and it must not be a repeat of a crime to qualify for diversion. Even if the act committed falls under the category of a criminal offense punishable by more than 7 (seven) years in prison and is a repeat offender, it is nevertheless subject to the juvenile criminal justice system.[14]

\section{Aspects of Efficiency in Legal Theory Building} Richard A Posner To Realize Restorative Justice Through Diversion.

Richard A Posner is one of the pioneers in the development of law and economics and a pioneer in the development of economic analysis of law (economic analysis of law), it was Posner who tried to use economic theory to analyze law. The legal and economic paradigm that developed in developed countries, including America in the 1970s, has changed the traditional view of jurists about law. The concept of human behavior in the eyes of the law which is only seen as "right" and "wrong" with respect to regulations, is changed to "risk" and "benefit" as the basis for the efficiency of human behavior. In the context of legal developments in Indonesia, according to Romli Atmasasmita, the development of economic analysis of law.[15]

This must be interpreted that so far criminal law is considered the only effective way to create a deterrent effect and prevent crime in society. With an economic approach and through an analysis of the benefits and losses in criminal law, it will be known how much negative impact the imposition of criminal sanctions has on the community, if it is associated with legal objectives for justice, certainty and benefit. Law always has many aspects in human life, social, cultural, economic, and political. Social life consisting of free individuals who have human rights to play a role and be productive in an economic growth guaranteed by the legal system. Therefore, it is clear that there is a relationship between the economy and the power of law in a social society. In the national context of the state, the economy is the backbone for the welfare of the people if it is supported by strong laws.[16]

According to Romli Atmasasmita, the importance of understanding microeconomic discipline on legal development in Indonesia is based on the following 7 (seven) reasons: (1) there are no parameters for the success of legal development; (2) law is a moving process; (3) the purpose of the state as stated in the fourth paragraph of the preamble to the 1945 Constitution of the Republic of Indonesia should be interpreted as a direction to create constructive collaboration between the disciplines of economics and the disciplines of law; (4) the concept of law enforcement must be based on a $2 \mathrm{R}$ approach (responsive and restorative) with a "cost and benefit ratio" analysis with the principles of maximization, balance and efficiency and using a mediation approach; (5) legal experts cannot ensure that the enacted law has been able to achieve the stated objectives; In the 1970s, which became a barometer for the formulation of public policies based on economic arguments (7) the use of microeconomic analysis in the application of criminal law would be able to identify the differences between administrative violations and criminal acts as early as possible.[17]

The purpose of the state for the welfare of the Indonesian people as mandated in the fourth paragraph of the Preamble to the 1945 Constitution of the Republic of Indonesia and the provisions of Article 1 Paragraph (3) as a state of law as well as provisions on judicial power and provisions on the national economy as regulated in Article 33 , must be interpreted as a direction that can create constructive collaboration between economic disciplines and legal disciplines to realize the ideals of the nation's founders, the welfare of the people.[18]

Based on microeconomic analysis, it is proven that the criminal justice process based on repressive laws is inefficient from the social, economic, political and financial aspects of the state. Therefore, according to Romli Atmasasmita, a change in orientation and foundation in law enforcement, especially for corruption, from a repressive legal orientation that prioritizes deterrence through punishment to responsive law and restorative law (Law 2R) [12]. Responsive law enforcement aims to make law enforcement seriously consider what is really needed by the Indonesian people and restorative law is law that can accommodate the restoration of social relations between perpetrators and 
victims (both individuals and the state). The $2 \mathrm{R}$ (responsive) law uses a "cost and benefit ratio" approach by applying the principles of maximization, balance and efficiency, while the $2 \mathrm{R}$ (restorative) law uses a mediation approach with the principle of balancing the interests of the victim and the perpetrator.[19]

According to Posner, microeconomic analysis can be used to assist legal science in analyzing legal events that are happening now and can predict with certainty and measurability regarding the building of legal politics in the future. Because so far, legal experts do not know whether a court decision that determines who wins and loses or settles cases through reconciliation between the parties can achieve the legal objectives, whether the laws (laws) that have been made have worked well in order to achieve the goals of the law. legal objectives in the form of public order, justice, certainty and benefit.[20]

The development of law and economics through a microeconomic analysis approach to law is very relevant and important for legal science because new knowledge will be obtained, namely the consideration of "cost and benefit ratio" in the formation of legislation and law enforcement so that the law does not work in a vacuum. According to Richard A Posner; "economic is a powerful tool for analyzing a vast range of legal questions"; here economics means rational choice and price theory, combined with the assumption that "resources tend to gravitate to their most valuable uses if voluntary exchange-market-is permitted", economics means rational choice and price theory combined with the assumption that.[21]

Richard Posner re-emphasizes the importance of economic factors in the legal system in his book The Economics of Justice, in which he reiterates his belief that "the logic of law, in many but not all cases, seems to lead to economic logic," and gives the example of judges interpreting common law as if they are attempting to maximize economic welfare. The idea of utilitarianism as a school that is contained in legal positivism, with the personalities Jeremy Bentham and John Stuarth Mill, has actually surfaced in the economy study of law.[22]

This utility theory highlights the concept of something's usefulness. As a result, something (esse) must benefit other esse (utility value) (social welfare). Following Ronald Coase and Richard A Posner's study, the concept of economic analysis in law evolved to incorporate transaction costs of the economy, economic institutions, and public choice. The efficiency of legal structures, the majority of which are related to private law, is related to transaction costs in the economy. The economy is concerned with human acts, such as formal legal laws, informal norms, traditions, and social rules. Meanwhile, by studying the micro economy and trade procedures, public choice is linked to the democratic decision-making process. Posner seeks to improve legal efficiency using economic principles, especially efficiency in promoting social welfare.[4]

In the context of the implementation of diversion in the settlement of criminal acts by children in realizing Restorative Justice, the most economical step is to understand diversion as a manifestation of the transaction cost of economy, economy institution and public choice. With regard to the efficiency of legal regulations that are intertwined with private law, diversion as a transfer of the settlement of children's cases from the criminal justice process to a process outside the criminal justice process must be based on the consent of the victim and/or family as well as the willingness of the perpetrator/child and their family. (Article 9 Paragraph (2) of the SPPA Law).[23]

From an economic point of view related to transaction costs in diversion, the victim and his family prior to giving consent already know / think about the risks of resolving conflicts due to criminal acts outside the court for their interests. However, if an agreement is not reached in the deliberation process, it is a risk that must be accepted. On the other hand, on the part of the perpetrator, the agreement for diversion will carry the risk of admitting guilt and accountability in the form of providing compensation to the victim, even if a diversion agreement is not reached, the perpetrator must bear the risk of undergoing a criminal justice process. [24]

The agreement for diversion by the perpetrators and victims and their families, in relation to the theory of utility, the actions of the parties must be based on the benefits that will be obtained with the agreement. If it is felt that the settlement through diversion/deliberation will not bring benefits, of course, approval will not be given. With diversion in the study of utility theory, it will bring benefits to both the perpetrator and the victim, because the perpetrator will be protected from negative stigma, as well as the victim will have the opportunity to obtain compensation.[25]

Deliberation as a form of diversion carried out between perpetrators, victims, families of victims and perpetrators and the community is actually a form of agreement in private law. Deliberations to resolve conflicts due to criminal acts can occur if there is equality in position between the parties. Restorative justice is an approach to justice based on the philosophy and values of responsibility, openness, trust, hope, healing and "inclusiveness" that focuses on reparation for losses due to criminal acts, in addition to encouraging perpetrators to be responsible for their actions, through providing opportunities the parties directly affected by the crime, namely victims, perpetrators and the community, by identifying and paying attention to their needs after the occurrence of a crime, and seeking a solution to the problem in the form of healing, reparation and reintegration and preventing further losses.[26]

In the implementation of the deliberation aimed at solving the problems resulting from the conflict, the first thing that must be done is the recognition of the perpetrator's guilt and an apology to the victim as well as the form of accountability of the perpetrator. On the other hand, the victim must be given the opportunity to express his opinion and the suffering experienced by the perpetrator's actions. The victim must also be heard for the desired solution to the suffering or loss suffered and the victim must also be willing to forgive the perpetrator. If each party can sincerely make an agreement to resolve 
the conflict then peace can be achieved and restorative justice can be realized.[27]

The implementation of diversion with mediation/consultation between perpetrators and victims seen from the cost and benefit ratio analysis is certainly more efficient than the settlement process through the criminal justice system with relatively large costs (budget for food costs for prisoners/convicts and the coaching process at LPKA) and a long time, while the time period for diversion is limited to a maximum of 30 days. Efficiency in this case is defined as an effort to increase welfare (wealth maximization) for victims and perpetrators in an economic context, and the law is created and applied for the main purpose of increasing the public interest (maximizing social utility).[28]

In relation to economic institutions related to human actions, including formal legal regulations, informal customs, traditions or social rules. Diversion based on the provisions stipulated in the SPPA Law is a form of formal legal regulation, the implementation of diversion in the form of deliberation is also a tradition or custom that already exists in our society in resolving conflicts (Development Forum in Javanese indigenous peoples and the Nagari Customary Density institution in the community). West Sumatran customs). Community Advisors, Professional Social Workers, Social Welfare Workers, and Community Leaders all play important roles in the execution of the deliberation.[29]

The Community Advisor is in responsibility of conducting community research for the child's benefit, as well as assisting, guiding, and supervising the diversion process and agreement execution. This social adviser plays an essential part in resolving the kid's case since it is the community advisor who has been researching the child from the beginning, therefore it is the community advisor who is familiar with the child's condition and best interests.[30]

Furthermore, the local community's traditions can be used as a basis for discourse in order to reach an agreement in settling issues between perpetrators and victims and their families. Amicable settlement is a tradition that grows and develops in the Indonesian customary law system. This is also in keeping with Pancasila's ideals as our country's ideology and foundation, particularly the concept of debate for consensus (fourth precept). As a result, using the diversion model to resolve children's issues is a conflict resolution approach based in the Indonesian nation's culture and customs.[31]

The diversion process, which is already a policy that must be implemented by legally appointed public officials, in this case law enforcement officers at all levels of criminal justice (investigators, prosecutors, public or judge), becomes a formal legal decision in the study of public choice, which is related to the democratic decision process by considering the micro-economy (the diversion agreement must be requested by a judge). Article 11 of the juvenile justice system law also regulates diversion agreements, which include: (a) reconciliation with or without compensation; (b) surrender to parents; (c) participation in education or training in educational institutions or social welfare organizing institutions for a maximum of 3 (three) months; or (d) community service. On the other hand, while diversion is carried out by discourse amongst the parties, perpetrators, and victims and their families, it is also a democratic process. The community advisor also oversees the implementation of the diversion agreement.[32]

Microeconomic theory, or the study of how limited resources are allocated between many conflicting purposes, informs the microeconomic analysis approach to criminal law. "An investigation into how scarce resources are distributed among competing goals." It is founded on three (three) principles: I optimization (maximization and minimization), (ii) balance, and (iii) efficiency. The welfare of people is linked to the three microeconomic concepts.

In diversion, the consent of the perpetrator and the victim is based on the calculation of profit and loss, which is the first microeconomic premise based on rational choice theory. Victims can express their suffering and losses as a result of the perpetrator's activities through diversion, with the prospect of gaining protection in the form of compensation or reparations/rehabilitation, but victims' interests are not always protected in the criminal justice system. The consent granted to the perpetrator will have significant benefits since it will prevent negative stigmatization, and the consequences that must be taken include accountability for the actions carried out in the form of confessing guilt and offering compensation/reparations. [33]

\section{CONCLUSION}

Based on the economisc of law analysis in Richard A Posner's legal theory building, the diversion model in the settlement of children's cases to realize restorative justice has fulfilled 3 (three) principles which include; Transaction cost of economy, Economy institution and Public choice. Meanwhile, according to the analysis of efficiency aspects in the view of Richard A Posner's legal theory, diversion in the settlement of children's cases which emphasizes restorative justice through deliberation between the perpetrator and the victim and their families can achieve the principle of balance (equilibrium) and the principle of efficiency, because in deliberation to resolve conflicts that arise, the interests of each party can be accommodated. The costs incurred in the criminal justice process can be reduced, including the cost of eating the convict.The emphasis on the principle of balance is on the interests of the victim, through the opportunity to express his desire for the suffering or loss experienced and whether it can be replaced by the perpetrator through the provision of compensation or otherwise the imposition of a crime gives a sense of justice to the victim.

\section{REFERENCES}

[1] R. Pradityo, "Restorative Justice Dalam Restorative Justice in Juvenile Justice System," J. Huk. dan Peradil., vol. 5, no. 3, pp. 
319-330, 2016.

[2] D. Mulyadi, M. R. Aridhayandi, D. F. Hukum, A. Fakultas, H. Universitas, and L. Jurdil, "PENYELESAIAN PERKARA PIDANA DENGAN KONSEP KEADILAN RESTORATIF (RESTORATIVE JUSTICE) DALAM SISTEM PERADILAN PIDANA TERPADU DI INDONESIA Kristian," J. Mimb. Justitia, vol. 1, no. 2, pp. 532-549, 2019

[3] Y. Ernis, "Diversi dan Keadilan Restoratif dalam Penyelesaian Perkara Tindak Pidana Anak di Indonesia," J. Ilm. Kebijak. Huk., vol. 10, no. 2, pp. 163-174, 2016.

[4] D. Aryadi, P. Pascasarjana, F. Hukum, and U. Diponegoro, "Implementasi keadilan restoratif dalam sistem peradilan pidana sebagai perwujudan nilai-nilai yang berwawasan pancasila," no. 1, pp. 85-101.

[5] Lilik Purwastuti Yudaningsih, "PENANGANAN PERKARA ANAK MELALUI RESTORATIVE JUSTICE,” J. Ilmu Huk., vol. 3, no. 1, pp. 67-79, 2014.

[6] L. Pembinaan et al., "Pembinaan Anak Pidana Di Lembaga Pembinaan Khusus Anak Dalam Perspektif Restorative Justice," Notarius, vol. 8, no. 2, pp. 342-353-353, 2015

[7] E. Sengi, "Restorative Justice Dalam Perkara Anak Di Pengadilan Negeri Tobelo," J. Refleks. Huk., vol. 2, no. April, pp. 153-166, 2018.

[8] I. W. D. C. Pratama, A. A. S. L. Dewi, and L. P. Suryani, "Upaya Paksa terhadap Pejabat yang Tidak Melakukan Putusan Pengadilan Tata Usaha Negara Denpasar," J. Prefer. Huk., vol. 1, no. 2, pp. $145-149,2020$.

[9] L. E. Susanti, "Economic Law Creation Beautiful Global Indonesia," Bestuur, vol. 7, no. 1, p. 47, 2020.

[10]L. Karjoko, Z. N. Rosidah, and I. G. A. K. R. Handayani, "Refleksi Paradigma Ilmu Pengetahuan Bagi Pembangunan Hukum Pengadaan Tanah Lego,” Bestuur, vol. 7, no. 2, pp. 1-14, 2019.

[11]Z. N. Rosidah, "Coherence of the Rules of Sharia Against Pancasila," Bestuur, vol. 8, no. 1, p. 40, 2020.

[12] Salma Suroyya Yuniyanti, "The Philosophical Foundation of the Coherence of Regulations Concerning Apartment in Indonesia," $J$. Moral. Leg. Cult., vol. 1, no. 1, pp. 18-23, 2020.

[13]I. D. M. Suartha, "Criminal Policy Formulation on Regulation of Death Penalties for Criminal Actors," J. Moral. Leg. Cult., vol. 1, no. 1 , p. 12, 2020.

[14]R. Saputra, Rian, Luthviat, "Institutionalization of the Approval Principle of Majority Creditors for Bankruptcy Decisions in Bankruptcy Act Reform Efforts," J. Moral. Leg. Cult., vol. 1, no. 2, pp. 93-102, 2020

[15]A. K. Jaelani and R. D. Luthviati, "The Crime Of Damage After the Constitutional Court's Decision Number 76 / PUU-XV / 2017," J. Hum. Rights, Cult. Leg. Syst., vol. 1, no. 1, pp. 31-41, 2021.

[16] S. D. Baranyanan, "Simplification of Law Regulations in Copyright Criminal Act Settlement," J. Hum. Rights, Cult. Leg. Syst., vol. 1, no. 2, pp. 80-91, 2021

[17]M. Jamil, "Fiduciary Security Arrangements and Issues in Indonesia," J. Hum. Rights, Cult. Leg. Syst., vol. 1, no. 2, pp. 109$119,2021$.

[18]Muthia Sakti, "Legal Protection for Sellers in the Use of Joint Accounts as One of the Payments in E-Commerce," J. Moral. Leg. Cult., vol. 1, no. 2, pp. 93-102, 2020.

[19]T. Triwanto and E. Aryani, "The Urgency of Granting Authority to Assess Corruption Justice Collaborators," Bestuur, vol. 8, no. 1, p. 60, 2020.

[20] Syahlan, "Effective and Efficient Synchronization in Harmonization of Regulations Indonesia," J. Hum. Rights, Cult. Leg. Syst., vol. 1, no. 1 , pp. $54-70,2021$.

[21]N. J. Santaularia, R. Larson, and C. Uggen, "Criminal punishment and violent injury in Minnesota," Inj. Epidemiol., vol. 8, no. 1, pp. $1-11,2021$.

[22]J. Goldstein, "Police Discretion Not to Invoke the Criminal Process: Low-Visibility Decisions in the Administration of Justice," Yale Law J., vol. 69, no. 4, p. 543, 1960.

[23]D. Fossati, E. Aspinall, B. Muhtadi, and E. Warburton, "Ideological representation in clientelistic democracies: The Indonesian case," Elect. Stud., vol. 63, no. December 2019, p. 102111, 2020.

[24] M. Sofiyuddin, S. Suyanto, S. Kadir, and S. Dewi, "Sustainable land preparation for farmer-managed lowland agriculture in Indonesia," For. Policy Econ., vol. 130, no. September 2020, p. 102534, 2021.

[25] A. Doraisami, "Macro-economic policy responses to financial crises in Malaysia, Indonesia and Thailand," J. Contemp. Asia, vol. 44, no.
4, pp. 581-598, 2014

[26]A. D. Nuryanto, "Problem Penyidikan Tindak Pidana Pencucian Uang yang Berasal dari Predicate Crime Perbankan," Bestuur, vol. 7 , no. 1 , p. 54,2019

[27]E. T. Gomez and E. Lafaye De Micheaux, "Diversity of Southeast Asian Capitalisms: Evolving State-Business Relations in Malaysia," J. Contemp. Asia, vol. 47, no. 5, pp. 792-814, 2017.

[28]H. Wagenaar, "Knowing' the rules: Administrative work as practice," Public Adm. Rev., vol. 64, no. 6, pp. 643-656, 2004.

[29]K. M. de Vries, "Transgender people of color at the center: Conceptualizing a new intersectional model," Ethnicities, vol. 15, no. 1 , pp. 3-27, 2015.

[30]U. K. Mishra and A. Negi, "Transgender and the Right to Employment in India: Analysing the Trajectories of Discrimination," Bestuur, vol. 9, no. 1, pp. 34-43, 2021.

[31]W. B. Putri et al., "Medicolegal Perspective on Physician-Induced Demand Issue," Bestuur, vol. 9, no. 1, pp. 106-124, 2021.

[32] Yuliandri, G. A. K. R. Handayani, T. Prasetyo, K. Seregig, and H. Tegnan, "Retributive justice theory and the application of the principle of sentencing proportionality in Indonesia," J. Leg. Ethical Regul. Issues, vol. 21, no. 4, pp. 1-8, 2018.

[33]F. S. Taxman, D. Soule, and A. Gelb, "Graduated sanctions: Stepping into accountable systems and offenders," Prison J., vol. 79, no. 2, pp. 182-204, 1999. 